\title{
Role of computed tomography tractography in evaluation of back/flank stab wounds
}

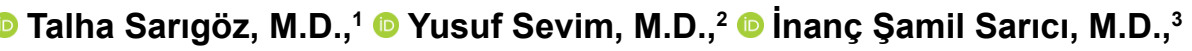 \\ (1) Ömer Topuz, M.D., ${ }^{2}$ (1) Tamer Ertan, M.D. ${ }^{2}$ \\ 1'Department of General Surgery, Develi Hatice-Muammer Kocatürk State Hospital, Kayseri-Turkey \\ ${ }^{2}$ Department of General Surgery, Kayseri City Hospital, Kayseri-Turkey \\ ${ }^{3}$ Department of General Surgery, Kanuni Sultan Süleyman Training and Research Hospital, İstanbul-Turkey
}

\begin{abstract}
BACKGROUND: The clinical approach to back/flank wounds has evolved over the years. The aim of this study was to discuss the potential of computed tomography tractography in patients with a stab wound to the back or flank.

METHODS: A total of 25 stable patients with stab wounds confined to the back/flank region were enrolled in this retrospective study. After initial resuscitation and physical examination, tractography was performed at the site of the stab wound. The patients subsequently underwent computed tomography with intravenous contrast.
\end{abstract}

RESULTS: Computed tomography tractography helped avoid a laparotomy in 15 (60\%) patients and accurately revealed a peritoneal breach in $10(40 \%)$ patients. No missed injuries were reported in the conservatively followed patients.

CONCLUSION: The addition of tractography to computed tomography is a safe, fast, and cost- and time-effective technique to evaluate back/flank stab wounds.

Keywords: Back injuries; laparotomy; peritoneum; stab; tomography; wound.

\section{INTRODUCTION}

In this modern era of assault weapons, it is easy to access firearms and knives that are the main cause of penetrating abdominal traumas. ${ }^{[1]}$ Therefore, trauma surgeons now more often encounter penetrating abdominal traumas. This is not the only thing that has changed in the last two decades. Also in the modern era of patient-focused healthcare, for surgeons, it is more important than ever to provide medico legal best practice. ${ }^{[2]}$ In this setting, accurate and early diagnosis of trauma patients is crucial.

Although there is no debate on patients who are hemodynamically unstable and who show peritoneal irritation findings need urgent surgery, there is still a lack of consensus about management of hemodynamically stable patients with stab wounds among surgeons. ${ }^{[3,4]}$ The previous trials with stable patients showed high rates of non-therapeutic laparotomies. Major concern here is that both negative laparotomy and non-operative management may increase morbidity and mortality rates in case of misdiagnosis. To assess anterior abdominal stab wounds, several methods are being discussed, especially local wound exploration that, according to the literature, reduced the number of negative laparotomies. ${ }^{[5]}$ Yet most of these techniques are inappropriate for wounds to the back and flank as the thickness of musculature and fat tissue in the retroperitoneal space prevents a good assessment. ${ }^{[6,7]}$

In this study, we aimed to find a safe, fast, and cost-effective technique to evaluate back and flank stab wounds. Our trial focused on the diagnostic accuracy and safety of computed tomography (CT) tractography.

Cite this article as: Sarı̈öz T, Sevim Y, Sarıcı İ̧, Topuz Ö, Ertan T. Role of computed tomography tractography in evaluation of back/flank stab wounds. Ulus Travma Acil Cerrahi Derg 2019;25:137-141.

Address for correspondence: Talha Sarıöz, M.D.

Develi Hatice-Muammer Kocatürk Devlet Hastanesi, Genel Cerrahi Kliniği, Kayseri, Turkey.

Tel: +90352 - 6216020 E-mail: sarigozt.md@gmail.com

Ulus Travma Acil Cerrahi Derg 2019;25(2):137-141 DOI: 10.5505/tjtes.2018.88107 Submitted: 16.04.2018 Accepted: 16.04.2018 Online: 14.03.2019

Copyright 2019 Turkish Association of Trauma and Emergency Surgery 


\section{MATERIALS AND METHODS}

This retrospective study was conducted at Kayseri Training and Research Hospital with an approval from Erciyes University Research Ethics Committee. From July 2012 to December 2017, 34 patients were admitted to the emergency department with stab wounds confined to back/flank. Boundaries of back were accepted as tip of scapula superiorly, iliac crest inferiorly, and posterior axillary lines laterally. Boundaries of flank were accepted as sixth intercostal space superiorly, iliac crest inferiorly, and posterior and anterior axillary lines laterally (Fig. I). ${ }^{[8]}$ Gunshot wounds, hemodynamically unstable patients (systolic blood pressure $<90 \mathrm{mmHg}$, heart rate $>100$, hemoglobin level $<10 \mathrm{~g} / \mathrm{dl}$ ), those unconscious, on physical examination with evisceration, had acute hemorrhage or peritonitis were excluded.

The CT examinations were based on dual-section spiral CT scanner (SOMATOM Emotion; Siemens Medical Solutions). This CT scanner can acquire images with slice thickness from I to $10 \mathrm{~mm}$. The images with $1.5-\mathrm{mm}$ slice thickness were used in this study. The site of stab wound was disinfected with 10\% povidone-iodine solution (Batticon, Adeka Co, Samsun, Turkey), and injection of $50-75 \mathrm{~mL}$ non-ionic contrast (iopromide, Ultravist; Bayer Schering Pharma AG, Berlin, Germany) was performed by using a $60 \mathrm{~mL}$ irrigation syringe with catheter tip through the wound irrigation to prevent overlapping of the tissue layers (Fig. 2). In addition, assessment of pain endured during tractography was performed

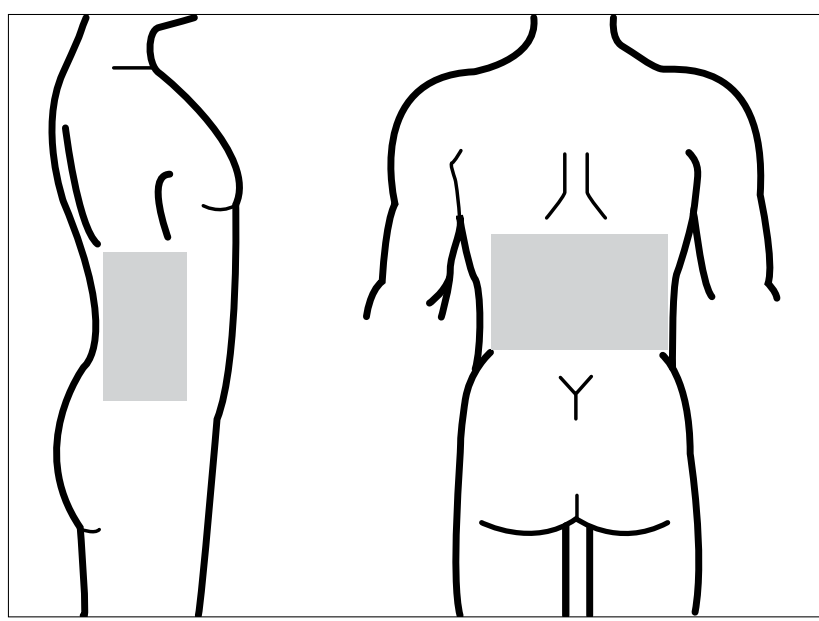

Figure 1. Boundaries of back: Tip of scapula superiorly, iliac crest inferiorly, and posterior axillary lines laterally. Boundaries of flank: Sixth intercostal space superiorly, iliac crest inferiorly, and posterior and anterior axillary lines laterally.

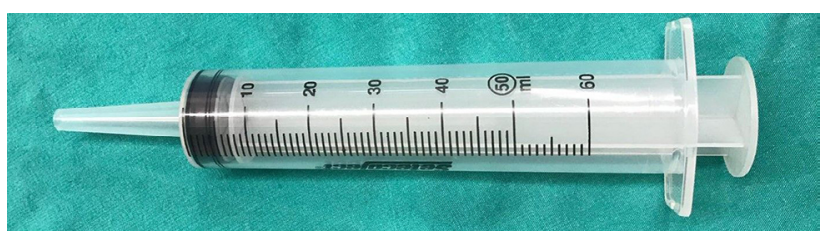

Figure 2. The 50-cc syringe with catheter tip used for tractography. by using a five-point verbal rating scale (VRS) with the words "no pain," "mild pain,” "moderate pain," "severe pain," and "unbearable pain." The patients were asked to rate intensity of pain by indicating which of the five words read aloud gave the best description. Later, CT with intravenous contrast was performed. All images were evaluated by a radiologist and trauma surgeons together in terms of peritoneal penetration and possible organ injury.

Subsequent to physical examination and CT tractography, organ injuries were graded according to The American Association for the Surgery of Trauma injury scoring scales. [9] Intraabdominal contrast in a CT scan was interpreted as positive tractography and indicator of peritoneal violation. Those were hospitalized, and they were observed with serial physical examination. In case of accompanying intraabdominal pathological finding such as definite organ injury, free air, or fluid, laparotomy was conducted. For the rest, conservative approach was selected, and patients without evident peritoneal breach and organ injury were discharged from emergency department (ED) to come to clinic control as an outpatient. Operative procedures were considered therapeutic if resection or repair was performed or hemostasis was required.

\section{RESULTS}

Of 34 patients, 9 patients required emergency surgery, and a total of 25 patients who gave their consent to participate were included in our trial. The mean age of the patients was $26 \pm 8$ years; $23(92 \%)$ patients were male, and 2 (8\%) patients were female. All of the patients had single wound. Knife was the stabbing object in 24 cases and screwdriver in I case. The most common location of stabbing was left flank followed by left back region. Of 25 patients, 15 (60\%) were discharged and called for control as an outpatient after initial physical examination and CT tractography confirmation of uneventful

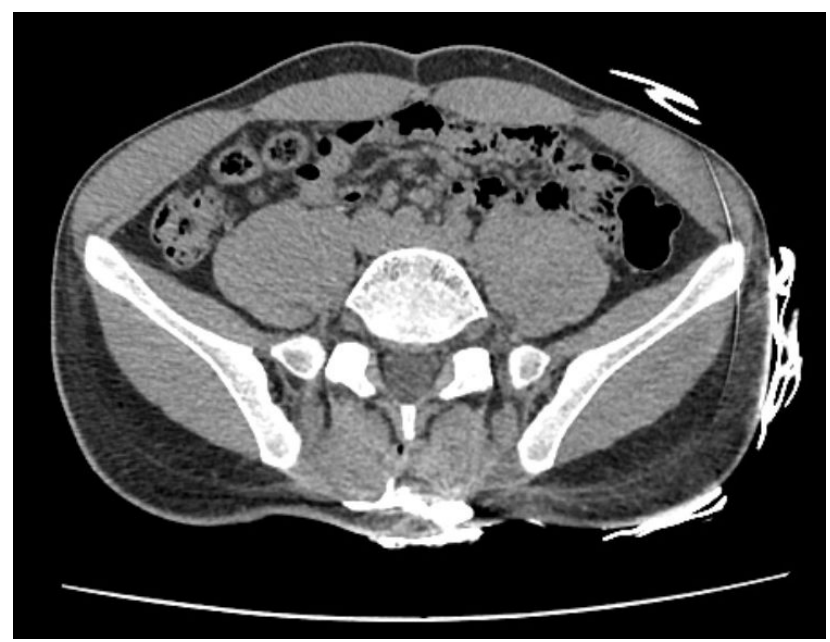

Figure 3. Abdominal computed tomography scan of the patient stabbed with screwdriver in the back showing negative peritoneal violation. Contrast agent is clearly seen in the tract as white. 
injury. But 10 of them (40\%) required hospitalization, and 7 of 10 required operative intervention due to organ injury detected in CT tractogram. The median (minimum, maximum) VRS score for pain was I (I, 3) (Figs. 3-5).

Left kidney (16\%) and descending colon (16\%) were the most common sites sustained injury. Resection and anastomosis for colon perforation was performed in four patients. Also, in one of them, splenectomy was added because of grade 3 spleen laceration. Furthermore, nephrectomy was performed in two patients due to grade 3-4 laceration, splenectomy, and diaphragmatic laceration repair in one patient. Of the remaining three patients, two were followed for grade I-2 left kidney injury, and one patient for retroperitoneal hematoma; but they did not require additional interference, and were also discharged after 24 hours of observation. Patients who were operated recovered without complication, and none of the conservatively followed patients represented with missed injury. Summary of patient demographics is presented in Table I.

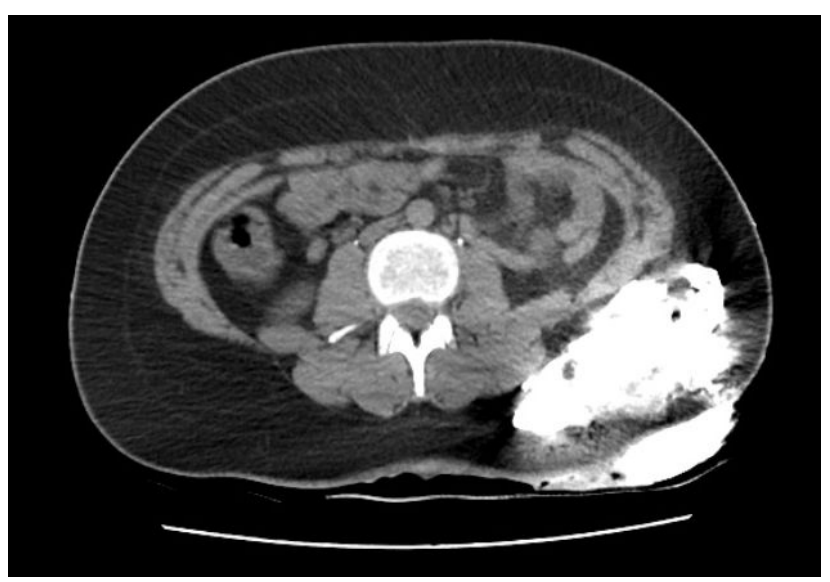

Figure 4. Abdominal computed tomography scan of an obese patient with retroperitoneal hematoma showing negative peritoneal violation. Contrast agent is clearly seen as white.

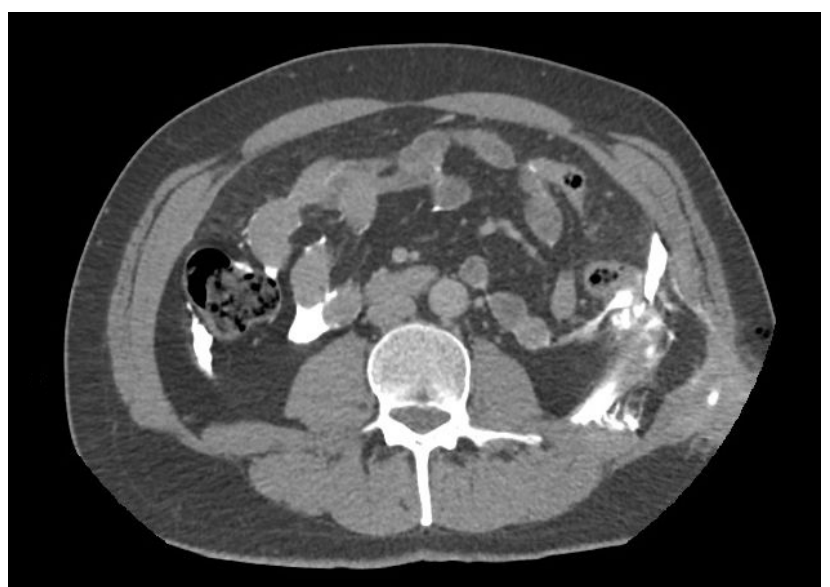

Figure 5. Abdominal computed tomography scan showing a patient with positive tractography. Leaked contrast agent through peritoneal defect is clearly seen around descending colon, ascending colon, and small intestines.
Table I. Demographics and some features of the patients managed with computed tomography tractography

\begin{tabular}{|c|c|c|}
\hline & $\mathbf{n}$ & $\%$ \\
\hline \multicolumn{3}{|l|}{ Gender } \\
\hline Male & 23 & 92 \\
\hline Female & 2 & 8 \\
\hline Age (years), mean $\pm S D$ & \multicolumn{2}{|c|}{$26 \pm 8$} \\
\hline \multicolumn{3}{|l|}{ Site of stab wound } \\
\hline Left flank & 13 & 52 \\
\hline Right flank & I & 4 \\
\hline Left back & 6 & 24 \\
\hline Right back & 5 & 20 \\
\hline \multicolumn{3}{|l|}{ Injury } \\
\hline None & 15 & 60 \\
\hline Descending colon & 3 & 12 \\
\hline Left kidney & 4 & 16 \\
\hline Descending colon+spleen & I & 4 \\
\hline Spleen+diaphragm & I & 4 \\
\hline Hematoma & I & 4 \\
\hline \multicolumn{3}{|l|}{ Verbal rating scale for pain } \\
\hline 1 & 17 & 68 \\
\hline 2 & 7 & 28 \\
\hline 3 & I & 4 \\
\hline \multicolumn{3}{|l|}{ Results of tractography } \\
\hline Positive penetration & 10 & 40 \\
\hline Negative penetration & 15 & 60 \\
\hline \multicolumn{3}{|l|}{ Final decision } \\
\hline Discharge & 15 & 60 \\
\hline Operative intervention & 7 & 28 \\
\hline Clinical observation & 3 & 12 \\
\hline \multicolumn{3}{|l|}{ Type of operation } \\
\hline Resection anastomosis & 4 & \\
\hline Nephrectomy & 2 & \\
\hline Splenectomy & 2 & \\
\hline Diaphragm repair & I & \\
\hline
\end{tabular}

SD: Standard deviation.

\section{DISCUSSION}

EDs are frontline for delivery of acute medical care. But increasing rates of inappropriate use, which is a worldwide problem for the last decade, causes medical, financial, and ethical problems. ${ }^{[10]}$ Overcrowding of EDs affects all aspects of healthcare quality. Long waiting times and resulting delays in treatment and difficulty in obtaining timely consultations endanger patients. Under these circumstances, early and accurate diagnosis of trauma patients becomes harder.

Patients with back/flank injury constitute one of the most 
challenging population for trauma surgeons in ED. Thick musculature, strong fascia, and lying soft tissues preclude adequate assessment. Also, injuries to retroperitoneal organs may not be present with physical findings. ${ }^{[1]}$ Therefore, diagnosis can be delayed, and it can result in morbidity and mortality if timely intervention is not performed.

Until the 20th century, penetrating abdominal traumas were being observed, and mortality rates were very high. After the Second World War, it was concluded that early laparotomy of such patients was life-saving. With the first proposal by Shaftan, in 1960, selective approach toward these patients has started being discussed. ${ }^{[12]}$ Shaftan and his colleagues convinced many surgeons that not all of penetrating abdominal traumas require surgery. Patients with wounds of the back/ flank underwent mandatory laparotomy till publication of Jackson and Thal in 1979. ${ }^{[13]}$ Physical examination, selected use of local wound exploration, and diagnostic peritoneal lavage formed core of early studies evaluating selective approach. ${ }^{6]}$ Later, CT was proposed as a diagnostic adjunct method to non-operative approach, and very low rates of non-therapeutic laparotomies were reported. ${ }^{[11,14]}$ The major objection to the use of CT was its accuracy for retroperitoneal organ perforations such as duodenum, colon had not been proven. ${ }^{[7]}$ Hence, different methods were formulated to reduce hospital costs and shorten unnecessary celiotomies over the years.

For the past two decades, triple contrast computed tomography $(3 C T)$ has been the focus of research in stable patients with back/flank injury. The rationale behind triple contrast is to increase diagnostic accuracy and evaluate upper and lower gastrointestinal system as well as major vascular structures in one imaging. As Pham and colleagues stated, this procedure takes time, and is not a rapid ED triage tool. ${ }^{[15]}$ McAllister et al. ${ }^{[16]}$ computed the time required for completion of $3 C T$ scan as $\mathbf{3 . 5}$ hours. According to Plorde and friends, one of the causes of a false-negative $3 \mathrm{CT}$ is inadequate filling of colon. [17] Since patient co-operation is needed for optimal contrast filling and considering strong association between high blood alcohol concentration and violence-related injury, feasibility of $3 C T$ is frequently at stake. ${ }^{[18,19]}$

We have previously reported our experience in patients with anterior abdominal stab wounds using CT tractography. ${ }^{[20]}$ Using contrast agent administered through stab wound helped identify peritoneal violation and avoid local wound exploration. Apart from that, we aimed to find its potential in back/ flank stab wounds. We hypothesized that addition of tractography to conventional $\mathrm{CT}$ with intravenous contrast would increase diagnostic ability to detect peritoneal breach, and we could use that to treat stable patients with back/flank stab wound injury confined to retroperitoneum conservatively. In their similar work, Bansal et al. ${ }^{[2]}$ inserted non-ionic contrast agent or povidone-iodine-soaked sterile sponges into stab wound to highlight wound tract and evaluate its penetration.
However, they indicated that patients with slash wounds or very small stab wounds could not undergo this technique. Another handicap of their method was that it required insertion of sponges into the wound either with sterile forceps or manually. This process may be also traumatic. Our choice of technique was primarily based on Katsoulas et al.'s ${ }^{[22]}$ case report. They used mixture of povidone-iodine and air for stab wound irrigation to reveal peritoneal breach and guide radiologist to the site of injury. Instead, we irrigated stab wound with non-ionic nearly $60 \mathrm{~mL}$ contrast dye and air. By irrigation, we managed to overcome overlapping of tissues and show peritoneal breach in $10(40 \%)$ patients accurately. Also 15 (60\%) were discharged following negative tractography. Moreover, tractogram was successful enough to show confines of injury in one of the discharged patient stabbed with screwdriver in the back who had relatively very small wound and in another discharged patient who was obese. The median time of evaluation for CT tractography was $23 \pm 3$ minutes including interpretation. Furthermore, this method was not painful as Yilmaz and friends ${ }^{[23]}$ indicated. We used VRS to assess pain endured during tractography, and most of the patients (68\%) responded as having no additional pain at all.

If injuries requiring operative intervention are diagnosed accurately and quickly, selective management can be successful. In our institution, CT tractography has been used as a safe, fast, cost-effective, and time-effective technique to evaluate both anterior abdominal and back/flank stab wounds. Practically, it can be safely performed in patients with slash or small sized wounds, obese patients, and patients with previous surgery. Implementation of CT tractography to our penetrating trauma algorithm resulted in shortened length of hospital stay and reduced number of non-therapeutic laparotomies. Prospective studies with a greater number of injuries, especially colon perforations and duodenum injuries, would be helpful to determine precise accuracy of CT tractography in patients with back/flank stab wound.

\section{Conflict of interest: None declared.}

\section{REFERENCES}

1. Venara A, Jousset N, Airagnes G Jr, Arnaud JP, Rougé-Maillart C. Abdominal stab wounds: self-inflicted wounds versus assault wounds. J Forensic Leg Med 2013;20:270-3. [CrossRef]

2. Girotti MJ, Leslie KA, Inman KJ, Chinnick B, Butcher C, Holliday RL. Attitudes toward trauma care of surgeons practising in Ontario. Can J Surg 1995;38:22-6.

3. Zuccon W, Paternollo R, Del Re L, Cordovana A, De Murtas G, Gaverini G, et al. Emergency treatment of violent trauma: clinical cases and surgical treatment of penetrating thoracoabdominal, perineal and anorectal trauma. Ann Ital Chir 2013;84:11-8.

4. Sugrue M, Balogh Z, Lynch J, Bardsley J, Sisson G, Weigelt J. Guidelines for the management of haemodynamically stable patients with stab wounds to the anterior abdomen. ANZ J Surg 2007;77:614-20.

5. Leppäniemi AK, Voutilainen PE, Haapiainen RK. Indications for early mandatory laparotomy in abdominal stab wounds. Br J Surg 
1999;86:76-80. [CrossRef]

6. Peck JJ, Berne TV. Posterior abdominal stab wounds. J Trauma 1981;21:298-306. [CrossRef]

7. Burns RK, Sariol HS, Ross SE. Penetrating posterior abdominal trauma. Injury 1994;25:429-31. [CrossRef]

8. Boyle EM Jr, Maier RV, Salazar JD, Kovacich JC, O'Keefe G, Mann FA, et al. Diagnosis of injuries after stab wounds to the back and flank. J Trauma 1997;42:260-5. [CrossRef]

9. Moore EE, Cogbill TH, Malangoni MA, Jurkovich GJ, Champion HR, Jurkovich GJ. Scaling system for organ specific injuries. Current Opinion in Critical Care 1996;2:450-62. [CrossRef]

10. Schwab CW. The future of emergency care for America: in crisis, at peril and in need of resuscitation! J Trauma 2006;61:771-3. [CrossRef]

11. Phillips T, Sclafani SJ, Goldstein A, Scalea T, Panetta T, Shaftan G. Use of the contrast-enhanced CT enema in the management of penetrating trauma to the flank and back. J Trauma 1986;26:593-601. [CrossRef]

12. Shaftan GW. Indications for operation in abdominal trauma. Am J Surg 1960;99:657-64. [CrossRef]

13. Jackson GL, Thal ER. Management of stab wounds of the back and flank. J Trauma 1979;19:660-4. [CrossRef]

14. Fletcher TB, Setiawan H, Harrell RS, Redman HC. Posterior abdominal stab wounds: role of CT evaluation. Radiology 1989;173:621-5. [CrossRef]

15. Pham TN, Heinberg E, Cuschieri J, Bulger EM, O'Keefe GE, Gross JA, et al. The evolution of the diagnostic work-up for stab wounds to the back and flank. Injury 2009;40:48-53. [CrossRef]

16. McAllister E, Perez M, Albrink MH, Olsen SM, Rosemurgy AS. Is triple contrast computed tomographic scanning useful in the selective management of stab wounds to the back? J Trauma 1994;37:401-3. [CrossRef]

17. Plorde JJ, Boyle EM Jr, Mann FA. Triple-contrast CT interrogation of the retroperitoneal colon after a stab wound. AJR Am J Roentgenol 1997;169:484. [CrossRef]

18. Rivara FP, Jurkovich GJ, Gurney JG, Seguin D, Fligner CL, Ries R, et al. The magnitude of acute and chronic alcohol abuse in trauma patients. Arch Surg 1993;128:907-12. [CrossRef]

19. Cherpitel CJ. Alcohol and injuries: a review of international emergency room studies since 1995. Drug Alcohol Rev 2007;26:201-14. [CrossRef]

20. Ertan T, Sevim Y, Sarigoz T, Topuz O, Tastan B. Benefits of CT tractography in evaluation of anterior abdominal stab wounds. Am J Emerg Med 2015;33:1188-90. [CrossRef]

21. Bansal V, Reid CM, Fortlage D, Lee J, Kobayashi L, Doucet J, et al. Determining injuries from posterior and flank stab wounds using computed tomography tractography. Am Surg 2014;80:403-7.

22. Katsoulas N, Ganapathi S, Hagger R. Wound irrigation before abdominal computed tomography scanning. Am J Emerg Med 2012;30:835.e1-4.

23. Yilmaz KB, Akinci M, Tamam S, Tokgoz S, Balas S, Akkoca M, et al. Comment on "What is the diagnostic value of computed tomography tractography in patients with abdominal stab wounds?" Eur J Trauma Emerg Surg 2017;43:279-80. [CrossRef]

\title{
ORIJINAL ÇALIŞMA - ÖZET
}

\section{Bilgisayarlı tomografi traktografinin sırt/flank delici-kesici alet yaralanmalarının değerlendirilmesindeki rolü \\ Dr. Talha Sarıgoz, ${ }^{1}$ Dr. Yusuf Sevim, ${ }^{2}$ Dr. İnanç Şamil Sarıcı, ${ }^{3}$ Dr. Ömer Topuz, ${ }^{2}$ Dr. Tamer Ertan ${ }^{2}$}

\author{
${ }^{1}$ Develi Hatice-Muammer Kocatürk Devlet Hastanesi, Genel Cerrahi Kliniği, Kayseri \\ ${ }^{2}$ Kayseri Şehir Hastanesi, Genel Cerrahi Kliniği, Kayseri \\ ${ }^{3}$ Kanuni Sultan Süleyman Eğitim ve Araştırma Hastanesi, Genel Cerrahi Klinği, İstanbul
}

AMAÇ: Sırt ve flank bölge delici alet yaralanmalarına klinik yaklaşım yıllar içinde değişim gösterdi. Bu yazıda, bilgisayarlı tomografi traktografinin sırt/ flank delici alet yaralanmalası olan hastalardaki potansiyelini tartışmak istedik.

GEREÇ VE YÖNTEM: Bu geriye dönük çalışmada, sırt/flank bölgeye sınırlı delici alet yaralanması olam toplam 25 hasta dahil edildi. İlk resüsitasyon ve fizik muayenenin ardından, traktografi delici alet yaralanmasından yapıldı. Sonrasında hastalara intravenöz kontrastlı bilgisayarı tomografi çekildi. BULGULAR: Bilgisayarlı tomografi traktografi 15 (\%60) hastada laparotomiden kaçınmaya ve 10 (\%40) hastada da periton ihlalini doğru olarak göstermemize yardımcı oldu. Konservatif olarak takip edilen hiç bir hasta gözden kaçmış yaralanma ile tekrar başvurmadı.

TARTIŞMA: Traktografinin bilgisayarlı tomografiye eklenmesi, sırt/flank delici alet yaralanmalarının değerlendirilmesinde güvenilir, hızlı, para ve zaman tasarruflu bir tekniktir.

Anahtar sözcükler: Delici; laparotomi; periton; sırt yaralanması; tomografi; yara.

Ulus Travma Acil Cerrahi Derg 2019;25(2):137-|41 doi: 10.5505/tjtes.20।8.88107 